\title{
Effect of Fertigation and Foliar Application of Nutrients on Yield and Quality of French Bean (Phaseolus vulgaris L.)
}

\author{
Udayakumar $^{1 *}$, G. Ramesh $^{2}$, Shekharagouda Patil ${ }^{1}$, Y. Pampanna ${ }^{1}$ and N. Anand ${ }^{3}$ \\ ${ }^{1}$ Department of Horticulture, College of Agriculture Raichur, University of Agricultural \\ Sciences, Raichur-584104, India \\ ${ }^{2}$ Department of Soil and Water Engineering, College of Agriculture Engineering, Raichur, \\ University of Agricultural Sciences, Raichur-584104, India \\ ${ }^{3}$ Department of Agronomy, College of Agriculture Raichur, University of Agricultural \\ Sciences, Raichur-584104, India \\ *Corresponding author
}

\section{A B S T R A C T}

\begin{tabular}{|l|}
\hline Ke y w o r d s \\
Clusters, Crude \\
fibre, Fertigation, \\
Firmness, \\
Vegetable special \\
\hline Article Info \\
\hline $\begin{array}{l}\text { Accepted: } \\
\text { 15 August } 2019 \\
\text { Available Online: } \\
\text { 10 September } 2019\end{array}$ \\
\hline
\end{tabular}

A field experiment was conducted to evaluate the effect of fertigation and foliar application of nutrients on yield and quality of french bean (Phaseolus vulgaris L.).The experiment consisted of four main plots i.e., different levels of fertigation and three sub plots i.e., foliar spray of different nutrient solutions. The experiment was conducted in split plot design and it was replicated thrice. 100 per cent RDF through fertigation and foliar application of 0.5 per cent vegetable special recorded maximum number of pods per clusters (7.87), more number of clusters per plant (6.73), yield per plant (171.73 g) and yield per hectare $(8.22 \mathrm{t})$.Quality parameters like higher pod length $(14.44 \mathrm{~cm})$, pod width $(0.9 \mathrm{~cm})$ and fresh pod weight $(10.33 \mathrm{~g})$ was also recorded in the same treatment. Higher shelf life, higher moisture content $(89.63 \%)$, higher firmness $\left(4.06 \mathrm{~kg} / \mathrm{cm}^{2}\right)$ and higher crude fibre content(16.48\%)was recorded in 100 per cent RDF through fertigation and foliar application of 0.5 per cent vegetable special compared to other treatments. The physiological loss in weight recorded on 2, 4, 6 and 8 days, exhibited lower values with 100 per cent RDF through fertigation and foliar application of 0.5 per cent vegetable special.

\section{Introduction}

French bean (Phaseolus vulgaris L.) is one of the most important leguminous vegetable. It is also known as common bean, bush bean, kidney bean, snap bean, haricot bean and navy bean. It is grown for the tender green beans as well as dry beans seeds (Rajmah). It is originated in warm temperate region of Central America (Mexico and Guatemala) and Southern America, mainly the Andean regions. There are two distinct gene pools of french bean, one is Andean origin and other is the Central America and Mexican origin. The wild species Phaseolus aborigineus is considered as the progenitor of Phaseolus 
vulgaris L. French bean is grown in different parts of the world for its mature dry seeds, immature tender green or yellow pods (snap bean) and for its leaves (in Africa and Asia), which is being used as vegetable. In Northern India, dry pods of french bean fetch higher price compared to other pulse crops as its vegetable preparation is considered to be one of the most nutritious and delicious dish for the 'Sunday special'. The dry seeds can also be canned and exported for vegetable purpose. Tender pods of french bean can be harvested at about 50-60 days after sowing for vegetable purpose.

French bean is quite nutritious and potential source of protein, carbohydrates and minerals. The mineral matter and crude fibre are concentrated in seeds, while crude protein and energy are stored in the cotyledons. It contains about $1.7 \mathrm{~g}$ protein, $0.8 \mathrm{~g}$ mineral matter, $1.8 \mathrm{~g}$ fibre, $0.1 \mathrm{~g}$ fat $4.5 \mathrm{~g}$ carbohydrates, $28 \mathrm{mg}$ phosphorus, $50 \mathrm{mg}$ calcium, $74 \mathrm{mg}$ potassium and $0.6 \mathrm{mg}$ iron per $100 \mathrm{~g}$ of edible part (Pandey and Singh, 2010).

Micronutrients such as boron, copper and zinc also play a positive role for increasing pod as well as seed yield in french bean. Micronutrients are those elements that are essential for plant growth, but are required in smaller quantity. If these micronutrients are not available sufficiently, plants will suffer from physiological stress due to inefficiency of several enzymatic systems and other related metabolic functions (Fageria, 2009).

Fertigation has immense utility in increasing the production of french bean. Foliar spray of micronutrients play an important role in increasing yields. In the past, some efforts have been made to study the influence of fertigation on vegetative and reproductive parameters of french bean. However the information on interactive effect of fertigation and foliar sprays of nutrients is lacking. Hence this study was taken up to assess the influence of fertigation on growth, yield and quality of french bean and to know the effect of foliar sprays on growth, yield and quality of french bean.

\section{Materials and Methods}

The experiment was conducted from November 2018 to February 2019 in the fields of All India Coordinated Research Project on Plasticulture Engineering Technology, at College of Agriculture Engineering, Raichur University of Agricultural Sciences, Raichur. This is located in the North Eastern dry zone i.e., Zone -II of the region -I in Karnataka. The location corresponds to $16^{0} 25$ North latitude and $77^{\circ} 33^{\circ}$ East longitude. The climate of the experimental location is semiarid and average annual rainfall is $722 \mathrm{~mm}$. The elevation of Raichur is $406 \mathrm{~m}$ above mean sea level (MSL).

French bean variety Arka Arjun was procured from Indian Institute of Horticulture Research, Bengaluru. Experiment was laid out in split plot design with twelve treatments and three replications. The treatments consisted of main plot treatments i.e., $\mathrm{M}_{1}-50 \%$ of RDF through fertigation, $\mathrm{M}_{2}-75 \%$ of $\mathrm{RDF}$ through fertigation, $\mathrm{M}_{3}-100 \%$ of $\mathrm{RDF}$ through fertigation and $\mathrm{M}_{4}-100 \% \quad \mathrm{RDF}$ as soil application and drip irrigation and sub plot treatments: $S_{1}-$ Foliar spray of humic acid $(2 \%), \mathrm{S}_{2}-$ Foliar spray of vegetable special $(0.5 \%)$ and $\mathrm{S}_{3^{-}}$Foliar spray of vermiwash $(5 \%)$. Fertigation was provided at weekly interval and foliar spray of micronutrients was taken up at 20, 40 and 60 DAS.

The land was thoroughly ploughed and brought to a fine tilt. Raised beds of $10 \mathrm{~m}$ length and $1 \mathrm{~m}$ width were prepared. French bean seeds were sown on the raised beds at a spacing of $45 \times 15 \mathrm{~cm}$. Drip laterals of $4 \mathrm{LPH}$ were placed on the beds. Irrigation and fertigation was provided as per the plan of the experiment. The required nitrogen, 
phosphorous and potassium was applied to the experimental plot through water soluble fertilizers (WSF) i.e. 19:19:19 and 00:52:34. Fertilizers were applied by pressure differential method by using venturi system. The required pressure was monitored by using pressure gauge fitted on the supply line just after the filter. Different growth promoting nutrients were used through foliar application i.e. Commercial formulation of humic acid used in the study, was brought from market, vegetable special was brought from Indian Institute of Horticultural Research, Bengaluru and vermiwash was procured from Entomology laboratory, University of Agricultural Sciences, Raichur. Five plants were tagged from each plot. Observations on growth parameters were recorded from these tagged plants at 15, 30, 45 DAS and at harvest. Yield parameters were recorded at harvest.

Analysis of variance was performed following the statistical method described by Panse and Sukhatme (1967) and the significance difference among the treatment means were calculated at 5 per cent level of significance.

\section{Results and Discussion}

\section{Yield and yield attributes}

Yield attributes like number of pods per clusters and number clusters per plant and yield parameters like, yield plant ${ }^{-1}(\mathrm{~g})$, yield $\mathrm{ha}^{-1}(\mathrm{t})$ are presented in table 2.Fertigation with 100 per cent RDF has recorded maximum number of pods per clusters (7.60), number of clusters per plant (6.47), yield plant $^{-1}(162.31 \mathrm{~g})$ and yield ha ${ }^{-1}(7.42 \mathrm{t})$. Foliar spray of 0.5 per cent vegetable special has exhibited maximum number of pods per clusters (7.00), more number clusters per plant (5.73), yield plant ${ }^{-1}(153.15 \mathrm{~g})$ and yield $\mathrm{ha}^{-1}$ $(7.04 \mathrm{t})$. Among the interactions, maximum number of pods per clusters (7.87), number of clusters per plant (6.73), yield plant $^{-1}(171.73$ g) and yield ha-1 $(8.22 \mathrm{t})$ was observed with 100 per cent RDF through fertigation and foliar spray of 0.5 per cent vegetable special.

Higher number of pods per clusters, number of clusters per plant, yield plant ${ }^{-1}(\mathrm{~g})$, and yield $\mathrm{ha}^{-1}(\mathrm{t})$ were noticed with 100 per cent RDF through fertigation and foliar spray of vegetable special. Higher doses of fertigation promotes the increase in number of leaves and leaf area which resulted in proper utilization of solar energy leading to increase in photosynthesis and higher dry matter accumulation in plants. Chlorophyll is an essential component in photosynthesis, which is increased by higher nitrogen content in the plants. Further phosphorous plays an important role in transformation of sugar to starch, transformation of ADP to ATP, vice versa and strengthening of roots of the plant (Patel and Patel1990). Potassium improves overall crop growth by playing an important role in photosynthesis and transpiration. Higher level of nitrogen, phosphorous and potassium at early stages of crop growth and critical stages i.e. at flowering and pod set might have resulted in production of more number of pods per plant. Foliar spray of micronutrients might have ameliorated the physical and chemical properties of soil, leading to adequate supply of nutrients. This further, might have increased the production and accumulation of carbohydrates (Basavarajeswari et al., 2008). Due to these reasons, the interaction of 100 per cent RDF through fertigation and foliar spray of vegetable special have resulted in higher yield parameters.

\section{Quality parameters}

Quality parameters like pod length, pod width, average fresh pod weight, physiological loss in weight, shelf life, moisture content, firmness and fibre content are presented in 
table 2, 3and 4 respectively. Longer pod length $(13.38 \mathrm{~cm})$, higher pod width $(0.85 \mathrm{~cm})$ and higher fresh pod weight $(9.48 \mathrm{~g})$ was obtained from 100 per cent RDF through fertigation and this was on par with 75 percent RDF through fertigation $(13.05 \mathrm{~cm})$. Foliar spray with 0.5 per cent vegetable special has yielded longer pod length $(13.70 \mathrm{~cm})$, higher pod width $(0.85 \mathrm{~cm})$ and higher fresh pod weight $(9.64 \mathrm{~g})$. The interaction between fertigation levels and foliar spray has shown significant difference. Fertigation with 100 per cent RDF and 0.5 per cent of vegetable special has shown longer pod length $(14.44 \mathrm{~cm})$, higher pod width $(0.90 \mathrm{~cm})$ and higher fresh pod weight $(10.33 \mathrm{~g})$ compared to other interaction effects.

Quality parameters like pod length, pod width, and average fresh pods weight were higher with 100 per cent RDF through fertigation. The maximum weight of fruit, width and length of fruit in the present study could be attributed to enhanced supply of nutrients through increased fertigation level in the root vicinity of plant, and optimum nutrient concentration in the root zone throughout the crop growth period.

Present findings are in accordance with Janapriya et al., (2010) who found significantly higher fruit yield and quality under increased fertigation level. Foliar application of vegetable special enhanced the quality parameters like pod length, pod width, and average fresh pod weight in the present study. This is due to adequate and continuous nutrient availability through soil and foliar nutrition promotes the supply of assimilates to sink thus enlarging the size of the yield structure. These could be the reasons for better quality of pods. The findings of Uma and Karthik (2017) have also confirmed the results of present study. The combined effect of 100 per cent RDF through fertigation and foliar spray of vegetable special has shown best quality parameters like pod length, pod width, and fresh pod weight. This might be due to better synthesis of cytokine with optimum supply of nitrogen and phosphorus resulting in more number of fruits (Premsekhar and Rajashree, 2009). Also better supply of potassium with its split application and supplementation of secondary and micro nutrients might have enhanced the fruit size (Batra et al., 2002), increased uptake of nutrients and better utilization of photosynthates resulting in drymatter accumulation in edible parts (Guievence and Badem, 2000).

100 per cent RDF through fertigation has shown lower physiological loss $(51.61 \%)$ in weight on $8^{\text {th }}$ day, higher shelf life of the pod (6.78 days), higher moisture content (87.81 $\%)$, higher firmness of pods $\left(3.65 \mathrm{~kg} / \mathrm{cm}^{2}\right)$ and higher crude fibre content $(15.90 \%)$. Foliar spray of 0.5 per cent vegetable special recorded lower physiological loss in weight $(53.54 \%)$ on $8^{\text {th }}$ day, higher shelf life of the pod (6.92 days), higher moisture content (86.74 \%), higher firmness of pods (3.69 $\left.\mathrm{kg} / \mathrm{cm}^{2}\right)$ and higher crude fibre content $(15.68$ $\%)$. Among the interaction between fertigation levels and foliar spray significant difference was observed.

Fertigation with 100 per cent RDF and 0.5 per cent of vegetable special has shown lower physiological loss in weight $(47.50 \%)$ on $8^{\text {th }}$ day, higher shelf life of the pod (8 days), higher moisture content (89.63\%), higher firmness of pods $\left(4.06 \mathrm{~kg} / \mathrm{cm}^{2}\right)$ and higher crude fibre content $(16.42 \%)$

Quality parameters like shelf life, moisture content, firmness and fibre content were best with 100 per cent RDF through fertigation. This is due to higher availability of nutrients in the vicinity of root zone which might have helped in more absorption of NPK. 
Table.1 Effect of different levels of fertigation and foliar spray of nutrients on yield and yield attributes in french bean

\begin{tabular}{|c|c|c|c|c|}
\hline Treatment & $\begin{array}{l}\text { Number of } \\
\text { pods per } \\
\text { clusters }\end{array}$ & $\begin{array}{l}\text { Number of } \\
\text { pod clusters } \\
\text { per plant }\end{array}$ & $\begin{array}{c}\text { Yield } \\
\operatorname{plant}^{-1}(g)\end{array}$ & $\begin{array}{l}\text { Yield } \\
\mathrm{ha}^{-1}(\mathrm{t})\end{array}$ \\
\hline \multicolumn{5}{|l|}{ Main plot } \\
\hline $\begin{array}{l}M_{1}-50 \% \text { RDF through } \\
\text { fertigation }\end{array}$ & 6.36 & 4.93 & 139.65 & 5.97 \\
\hline $\begin{array}{l}M_{2}-75 \% \text { RDF through } \\
\text { fertigation }\end{array}$ & 7.02 & 5.64 & 148.60 & 6.45 \\
\hline $\begin{array}{l}M_{3}-100 \% \text { RDF through } \\
\text { fertigation }\end{array}$ & 7.60 & 6.47 & 162.31 & 7.42 \\
\hline $\begin{array}{l}\mathrm{M}_{4}-100 \mathrm{RDF} \text { as soil } \\
\text { application }\end{array}$ & 6.07 & 5.24 & 139.05 & 6.23 \\
\hline SEm \pm & 0.08 & 0.06 & 1.66 & 0.04 \\
\hline CD at $5 \%$ & 0.26 & 0.21 & 5.87 & 0.15 \\
\hline \multicolumn{5}{|l|}{ Sub plot } \\
\hline $\begin{array}{l}S_{1} \text {-Foliar spray of humic } \\
\text { acid }(2 \%)\end{array}$ & 6.73 & 5.45 & 147.54 & 6.53 \\
\hline $\begin{array}{l}S_{2} \text {-Foliar spray of } \\
\text { vegetable special }(0.5 \%)\end{array}$ & 7.00 & 5.73 & 153.15 & 7.04 \\
\hline $\begin{array}{l}S_{3} \text {-Foliar spray of } \\
\text { vermiwash }(5 \%)\end{array}$ & 6.55 & 5.53 & 141.52 & 5.98 \\
\hline SEm \pm & 0.05 & 0.07 & 1.23 & 0.09 \\
\hline CD at $5 \%$ & 0.17 & 0.22 & 3.71 & 0.26 \\
\hline \multicolumn{5}{|l|}{ Interaction } \\
\hline $\mathbf{M}_{1} \mathbf{S}_{1}$ & 6.07 & 4.87 & 137.00 & 6.34 \\
\hline $\mathbf{M}_{1} \mathbf{S}_{2}$ & 6.67 & 5.20 & 145.87 & 6.40 \\
\hline $\mathbf{M}_{1} \mathbf{S}_{3}$ & 6.33 & 4.73 & 136.08 & 5.19 \\
\hline $\mathbf{M}_{2} \mathbf{S}_{1}$ & 7.07 & 5.33 & 151.13 & 6.21 \\
\hline $\mathbf{M}_{2} \mathbf{S}_{2}$ & 7.13 & 5.60 & 148.73 & 6.92 \\
\hline $\mathbf{M}_{2} \mathbf{S}_{3}$ & 6.87 & 6.00 & 145.93 & 6.22 \\
\hline $\mathbf{M}_{3} \mathbf{S}_{1}$ & 7.60 & 6.27 & 163.73 & 7.33 \\
\hline $\mathbf{M}_{3} \mathbf{S}_{2}$ & 7.87 & 6.73 & 171.73 & 8.22 \\
\hline $\mathbf{M}_{3} \mathbf{S}_{3}$ & 7.33 & 6.40 & 151.47 & 6.71 \\
\hline $\mathbf{M}_{4} \mathbf{S}_{1}$ & 6.20 & 5.33 & 138.29 & 6.25 \\
\hline $\mathbf{M}_{4} \mathbf{S}_{2}$ & 6.33 & 5.40 & 146.27 & 6.62 \\
\hline $\mathbf{M}_{4} \mathbf{S}_{3}$ & 5.67 & 5.00 & 132.60 & 5.82 \\
\hline SEm \pm & 0.11 & 0.14 & 2.45 & 0.17 \\
\hline CD at $5 \%$ & 0.33 & 0.44 & 7.34 & 0.52 \\
\hline
\end{tabular}


Table.2 Effect of different levels of fertigation and foliar spray of nutrients on quality parameters in french bean

\begin{tabular}{|c|c|c|c|}
\hline Treatment & $\begin{array}{l}\text { Pod length } \\
\text { (cm) }\end{array}$ & $\begin{array}{l}\text { Pod width } \\
\text { (cm) }\end{array}$ & $\begin{array}{l}\text { Fresh pod } \\
\text { weight }(g)\end{array}$ \\
\hline \multicolumn{4}{|l|}{ Main plot } \\
\hline$M_{1}-50 \%$ RDF through fertigation & 12.94 & 0.80 & 8.56 \\
\hline$M_{2}-75 \%$ RDF through fertigation & 13.05 & 0.84 & 9.33 \\
\hline$M_{3}-100 \%$ RDF through fertigation & 13.38 & 0.85 & 9.48 \\
\hline $\mathrm{M}_{4}-100 \mathrm{RDF}$ as soil application & 12.77 & 0.79 & 8.38 \\
\hline $\operatorname{SEm} \pm$ & 0.11 & 0.01 & 0.19 \\
\hline CD at $5 \%$ & 0.38 & 0.03 & 0.68 \\
\hline \multicolumn{4}{|l|}{ Sub plot } \\
\hline$S_{1}$-Foliar spray of humic acid ( $\left.2 \%\right)$ & 12.81 & 0.81 & 8.78 \\
\hline $\begin{array}{l}S_{2} \text {-Foliar spray of vegetable special } \\
(0.5 \%)\end{array}$ & 13.70 & 0.85 & 9.64 \\
\hline $\mathrm{S}_{3}$-Foliar spray of vermiwash $(5 \%)$ & 12.60 & 0.79 & 8.38 \\
\hline SEm \pm & 0.13 & 0.01 & 0.13 \\
\hline CD at $5 \%$ & 0.40 & 0.02 & 0.41 \\
\hline \multicolumn{4}{|l|}{ Interaction } \\
\hline $\mathbf{M}_{1} \mathbf{S}_{1}$ & 13.11 & 0.79 & 8.73 \\
\hline $\mathbf{M}_{1} \mathbf{S}_{2}$ & 12.63 & 0.84 & 8.73 \\
\hline $\mathbf{M}_{1} \mathbf{S}_{3}$ & 13.09 & 0.77 & 8.20 \\
\hline $\mathbf{M}_{2} \mathbf{S}_{1}$ & 12.83 & 0.82 & 9.53 \\
\hline $\mathbf{M}_{2} \mathbf{S}_{2}$ & 13.42 & 0.87 & 9.90 \\
\hline $\mathbf{M}_{2} \mathbf{S}_{3}$ & 12.90 & 0.81 & 8.56 \\
\hline $\mathbf{M}_{3} \mathbf{S}_{1}$ & 12.88 & 0.82 & 8.93 \\
\hline $\mathbf{M}_{3} \mathbf{S}_{2}$ & 14.44 & 0.90 & 10.33 \\
\hline $\mathbf{M}_{3} \mathbf{S}_{3}$ & 12.82 & 0.82 & 9.17 \\
\hline $\mathbf{M}_{4} \mathbf{S}_{1}$ & 12.42 & 0.81 & 7.93 \\
\hline $\mathbf{M}_{4} \mathbf{S}_{2}$ & 14.29 & 0.80 & 9.60 \\
\hline $\mathbf{M}_{4} \mathbf{S}_{3}$ & 11.59 & 0.77 & 7.60 \\
\hline SEm \pm & 0.26 & 0.01 & 0.27 \\
\hline CD at $5 \%$ & 0.78 & 0.03 & 0.80 \\
\hline
\end{tabular}


Table.3 Effect of different levels of fertigation and foliar spray of nutrients on physiological loss in weight in french bean

\begin{tabular}{|c|c|c|c|c|}
\hline \multirow[t]{2}{*}{ Treatment } & \multicolumn{4}{|c|}{ Physiological loss in weight (\%) } \\
\hline & $2^{\text {nd }}$ Day & $4^{\text {th }}$ Day & $6^{\text {th }}$ Day & $8^{\text {th }}$ Day \\
\hline \multicolumn{5}{|l|}{ Main plot } \\
\hline $\begin{array}{l}\mathrm{M}_{1}-50 \% \text { RDF through } \\
\text { fertigation }\end{array}$ & 10.39 & 32.11 & 46.89 & 56.78 \\
\hline $\begin{array}{l}M_{2}-75 \% \text { RDF through } \\
\text { fertigation }\end{array}$ & 11.00 & 33.67 & 45.33 & 53.78 \\
\hline $\begin{array}{l}M_{3}-100 \% \text { RDF through } \\
\text { fertigation }\end{array}$ & 10.56 & 32.33 & 44.44 & 51.61 \\
\hline $\begin{array}{l}\mathrm{M}_{4}-100 \mathrm{RDF} \text { as soil } \\
\text { application }\end{array}$ & 11.11 & 37.11 & 50.89 & 58.67 \\
\hline SEm \pm & 0.90 & 0.94 & 0.76 & 1.20 \\
\hline CD at $5 \%$ & NS & 3.33 & 2.67 & 4.24 \\
\hline \multicolumn{5}{|l|}{ Sub plot } \\
\hline $\begin{array}{l}S_{1} \text {-Foliar spray of humic } \\
\text { acid }(2 \%)\end{array}$ & 10.50 & 33.17 & 45.92 & 55.08 \\
\hline $\begin{array}{l}S_{2} \text {-Foliar spray of vegetable } \\
\text { special }(0.5 \%)\end{array}$ & 10.75 & 32.75 & 45.00 & 53.54 \\
\hline $\begin{array}{l}\mathbf{S}_{3} \text {-Foliar spray of } \\
\text { vermiwash }(5 \%)\end{array}$ & 11.04 & 35.50 & 49.75 & 57.00 \\
\hline SEm \pm & 0.50 & 0.73 & 0.59 & 0.91 \\
\hline CD at 5\% & NS & 2.21 & 1.78 & 2.74 \\
\hline \multicolumn{5}{|l|}{ Interaction } \\
\hline $\mathbf{M}_{1} \mathbf{S}_{1}$ & 9.67 & 31.67 & 46.00 & 55.00 \\
\hline $\mathbf{M}_{1} \mathbf{S}_{2}$ & 11.67 & 32.67 & 47.33 & 58.67 \\
\hline $\mathbf{M}_{1} \mathbf{S}_{3}$ & 9.83 & 32.00 & 47.33 & 56.67 \\
\hline $\mathbf{M}_{2} \mathbf{S}_{1}$ & 10.33 & 33.33 & 45.00 & 51.33 \\
\hline $\mathbf{M}_{2} \mathbf{S}_{2}$ & 10.33 & 33.33 & 42.33 & 53.00 \\
\hline $\mathbf{M}_{2} \mathbf{S}_{3}$ & 12.33 & 34.33 & 48.67 & 57.00 \\
\hline $\mathbf{M}_{3} \mathbf{S}_{1}$ & 10.83 & 33.00 & 44.67 & 55.33 \\
\hline $\mathbf{M}_{3} \mathbf{S}_{2}$ & 9.83 & 30.00 & 41.33 & 47.50 \\
\hline $\mathbf{M}_{3} \mathbf{S}_{3}$ & 11.00 & 34.00 & 47.33 & 52.00 \\
\hline $\mathbf{M}_{4} \mathbf{S}_{1}$ & 11.17 & 34.67 & 48.00 & 58.67 \\
\hline $\mathbf{M}_{4} \mathbf{S}_{2}$ & 11.17 & 35.00 & 49.00 & 55.00 \\
\hline $\mathbf{M}_{4} \mathbf{S}_{3}$ & 11.00 & 41.67 & 55.67 & 62.33 \\
\hline SEm \pm & 1.53 & 1.63 & 1.18 & 1.81 \\
\hline CD at $5 \%$ & NS & NS & 3.53 & 5.43 \\
\hline
\end{tabular}


Table.4 Effect of different levels of fertigation and foliar spray of nutrients on quality parameters in french bean

\begin{tabular}{|c|c|c|c|c|}
\hline Treatment & $\begin{array}{c}\text { Shelf life } \\
\text { (Days) }\end{array}$ & $\begin{array}{c}\text { Moisture } \\
\text { content (\%) }\end{array}$ & $\begin{array}{c}\text { Firmness } \\
\left(\mathbf{k g} / \mathrm{cm}^{2}\right)\end{array}$ & $\begin{array}{l}\text { Crude fibre } \\
\text { content }(\%)\end{array}$ \\
\hline \multicolumn{5}{|l|}{ Main plot } \\
\hline $\begin{array}{l}\mathrm{M}_{1}-50 \% \text { RDF through } \\
\text { fertigation }\end{array}$ & 6.44 & 84.46 & 3.35 & 15.24 \\
\hline $\begin{array}{l}M_{2}-75 \% \text { RDF through } \\
\text { fertigation }\end{array}$ & 6.67 & 86.08 & 3.47 & 15.21 \\
\hline $\begin{array}{l}M_{3}-100 \% \text { RDF through } \\
\text { fertigation }\end{array}$ & 6.78 & 87.81 & 3.65 & 15.90 \\
\hline $\begin{array}{l}\mathrm{M}_{4}-100 \mathrm{RDF} \text { as soil } \\
\text { application }\end{array}$ & 6.00 & 82.01 & 3.36 & 15.25 \\
\hline SEm \pm & 0.14 & 0.79 & 0.06 & 0.03 \\
\hline CD at $5 \%$ & 0.48 & 2.72 & 0.22 & 0.09 \\
\hline \multicolumn{5}{|l|}{ Sub plot } \\
\hline $\begin{array}{l}\text { S}_{1} \text {-Foliar spray of humic } \\
\text { acid }(2 \%)\end{array}$ & 6.33 & 84.63 & 3.37 & 15.13 \\
\hline $\begin{array}{l}S_{2} \text {-Foliar spray of vegetable } \\
\text { special }(0.5 \%)\end{array}$ & 6.92 & 86.74 & 3.69 & 15.68 \\
\hline $\begin{array}{l}\text { S }_{3} \text {-Foliar spray of } \\
\text { vermiwash }(5 \%)\end{array}$ & 6.17 & 83.90 & 3.32 & 15.40 \\
\hline SEm \pm & 0.09 & 0.42 & 0.02 & 0.02 \\
\hline CD at $5 \%$ & 0.27 & 1.26 & 0.07 & 0.06 \\
\hline \multicolumn{5}{|l|}{ Interaction } \\
\hline $\mathbf{M}_{1} \mathbf{S}_{1}$ & 6.33 & 84.23 & 3.26 & 13.73 \\
\hline $\mathbf{M}_{1} \mathbf{S}_{2}$ & 6.67 & 86.00 & 3.48 & 15.64 \\
\hline $\mathbf{M}_{1} \mathbf{S}_{3}$ & 6.33 & 83.13 & 3.32 & 16.35 \\
\hline $\mathbf{M}_{2} \mathbf{S}_{1}$ & 6.67 & 84.90 & 3.38 & 14.24 \\
\hline $\mathbf{M}_{2} \mathbf{S}_{2}$ & 7.00 & 86.83 & 3.71 & 14.93 \\
\hline $\mathbf{M}_{2} \mathbf{S}_{3}$ & 6.33 & 86.50 & 3.30 & 16.46 \\
\hline $\mathbf{M}_{3} \mathbf{S}_{1}$ & 6.33 & 86.57 & 3.53 & 16.46 \\
\hline $\mathbf{M}_{3} \mathbf{S}_{2}$ & 8.00 & 89.63 & 4.06 & 16.42 \\
\hline $\mathbf{M}_{3} \mathbf{S}_{3}$ & 6.00 & 87.23 & 3.37 & 14.83 \\
\hline $\mathbf{M}_{4} \mathbf{S}_{1}$ & 6.00 & 82.80 & 3.29 & 16.07 \\
\hline $\mathbf{M}_{4} \mathbf{S}_{2}$ & 6.00 & 84.50 & 3.50 & 15.73 \\
\hline $\mathbf{M}_{4} \mathbf{S}_{3}$ & 6.00 & 78.72 & 3.28 & 13.94 \\
\hline SEm \pm & 0.18 & 0.84 & 0.05 & 0.04 \\
\hline CD at $5 \%$ & 0.54 & 2.52 & 0.14 & 0.13 \\
\hline
\end{tabular}


Nitrogen, phosphorus and potassium are most indispensable for growth and development of the plant, as these are the basic fundamental constituents of all living matter. Thus, they increase the carbohydrates, and proteins in the reproductive parts as well. This might have helped in higher dry matter accumulation in pods of french beans. Hence, the pods have shown higher moisture content, fibre content, firmness, good shelf life and less physiological loss in weight. Foliar application of vegetable special enhanced the post-harvest parameters like shelf life, moisture content, firmness and fibre content. At the same time physiological loss in weight was lower. The increase in dry matter production in plants due to foliar spray of vegetable special might have resulted in greater accumulation of photosynthates by vegetative parts and its subsequent translocation to the sink. This ultimately improved the post-harvest parameters in french bean. Similar results were given by Pandita et al., (1976) and Singh et al., (2003).The combined effect of 100 per cent RDF through fertigation and foliar spray of 0.5 per cent vegetable special, exhibited higher values for moisture content, firmness, fibre content, and lower values for physiological loss in weight. This could be due to the absorption of readily available micronutrients through the foliage of the plant, as a result of foliar spray. The favourable environment created due to the conjunctive availability of macronutrients and micronutrients increased the accumulation of carbohydrates in the sink, thus resulting in better quality of french beans.

From the investigation, it can be concluded that the application of $100 \%$ RDF through fertigation exhibited higher pod yield and good quality pods. Thus, drip fertigation helps to improve pod yield and pod quality of french bean, compared to conventional method of fertilizer application. Foliar spray of 0.5 per cent vegetable special resulted in higher yield and good quality pods. Combined effect of 100 per cent RDF through fertigation and foliar spray of 0.5 per cent vegetable special also showed improved pod yield and quality of french bean pods, compared to other interactions. From the present research, we can concluded that 100 per cent RDF through fertigation and 0.5 per cent foliar spray of vegetable special is suitable for the cultivation of french bean as it provides higher yields and good quality pods.

\section{Acknowledgement}

The authors acknowledge All India Coordinated Research Project on Plasticulture Engineering Technology, Raichur for extending the support during the conduct of present research.

\section{References}

Basavarajeswari, C, P., Hosamni R, M., Ajjappalavara, P, S., Naik, B, H., Smitha, R, P., 2008. Effect of foliar application of micronutrients on growth, yield components of Tomato (Lycopersicon esculentum Mill): Karnataka J. Agri. Sci. 21(3):428-430.

Batra, V. K., Singh, B. and Singh, V., 2002. Response of brinjal to foliar feeding of water soluble fertilizers. International conference on vegetables, 11-14 at Bengaluru (Karnataka) India.

Fageria, N. K., 2009. The use of nutrients in crop plants, CRS Press, Taylor and Francis group.

Guievence, I., Badem. H., 2000. Effect of foliar application of different sources and levels of nitrogen on growth and yield of tomato. Indian J. Agric. Sci., 72(2): 104-105.

Janapriya, S., Palanisamy, D. and Ranghaswami, M. V., 2010. Soilless media and fertigation for naturally 
ventilated polyhouse production of cucumber (Cucumis sativus L.) cv Green Long. Int. J. Agric. Envi Biotech., 3(2): 199-205.

Pandey, A. K. and Singh, M., 2010. Legume Vegetables. Ashim printline, Delhi. pp. 101.

Pandita, M. L., Arora, S. K. and Singh, K., 1976. Effect of plant growth regulators on fruit set, early and total yield of tomato variety HS-101 (Lycopersicon esculentum Mill.) during summer season. Haryana J. Hort. Sci., 8(3 and 4): 112-116.

PanseV. G. and Sukhatme,P. V. 1967. "Statistical Methods for Agricultural Workers," 2nd Edition, Indian Council of Agricultural Research, New Delhi, pp.381.
Patel, J. J. and Patel, A. T., 1990. Effect of nitrogen and phosphorus levels on growth and yield of onion (Allium cepa L.) cultivar Pusa Red. Gujarat Agric. Uni. Res. J., 15(2): 1-5

Premsekhar, M. and Rajashree, V., 2009. Performance of hybrid tomato as influenced by foliar feeding of watersoluble fertilizers. Am. Eurasian J. Sustain. Agric., 3(1): 33-36.

Singh, M., Batra, V. K., Bhatia, A. K., Singh, V. and Arora, S. K. 2003. Response of foliar application of micronutrients on tomato variety "Hisar Arun". Veg. Sci., 30(2): 182-184.

Uma, M. M., and Karthik, A., 2017. Effect of foliar nutrition on growth, yield attributes and seed yield of pulse crops. Adv. Crop Sci. Tech., 5: 3

\section{How to cite this article:}

Udayakumar, G. Ramesh, Shekharagouda Patil, Y. Pampanna and Anand, N. 2019. Effect of Fertigation and Foliar Application of Nutrients on Yield and Quality of French Bean (Phaseolus vulgaris L.). Int.J.Curr.Microbiol.App.Sci. 8(09): 812-821. doi: https://doi.org/10.20546/ijcmas.2019.809.097 